\title{
DAMPAK PENERAPAN BEA KELUAR KARET ALAM INDONESIA Suatu Analisis Simulasi
}

\author{
Impact of Export Tax Application on Indonesian Natural Rubber \\ A Simulation Analysis \\ Sinung HENDRATNO \\ Pusat Penelitian Karet, Jalan Salak No 1 Bogor 16151
}

Diterima tanggal 29 Maret 2012 / Disetujui tanggal 17 Juli 2012

\begin{abstract}
The Government of Indonesia will encourage the development of domestic rubber goods industry. One effort is to plan the imposition of the rubber export tax. This paper analyze the impact of the imposition on Indonesian natural rubber export tax. Analysis was made using secondary data obtained from related sources and research results. Data were analyzed using a comparative static methods and simulation. The results of simulation analysis showed that the application of rubber export tax would lower prices at the wholesale and rubber producers (farmers and companies). Application of rubber export taxes also had some impacts on the following: a) an increase in the domestic consumption of rubber goods, b) a decrease in the total national production, c) an increase in the government revenue and d) an accurrence of economic loss to rubber society. Application of rubber export tax policy should be conducted in association with other policies (mixed policy ) as: a) the protection of the welfare policy of the producer, b) the security policy against illegal trade in raw rubber material, c) the policy on provision of supporting materials for industrial rubber goods and reduction/elimination of tax added value for primary products, and d) the policy on exchange rate stabilization (managed floating exchange rate).
\end{abstract}

Keywords: export tax, rubbergoods industry, welfare, natural rubber

\section{Abstrak}

Pemerintah akan mendorong pengembangan industri barang jadi karet di dalam negeri. Salah satu upayanya adalah dengan merencanakan penerapan bea keluar karet. Artikel ini menganalisis dampak dari penerapan bea keluar karet alam Indonesia. Analisis menggunakan data sekunder yang diperoleh dari berbagai sumber yang relevan dan hasil penelitian. Data dianalisis dengan menggunakan metode komparatif statik dan simulasi. Hasil analisis simulasi menunjukkan bahwa penerapan bea keluar karet akan menurunkan harga di tingkat perdagangan besar dan produsen (petani dan perusahaan) karet. Penerapan bea keluar karet juga berdampak pada: a) meningkatnya surplus konsumen industri barang jadi karet, b) menurunnya surplus produsen, c) menghasilkan penerimaan pemerintah, dan d) terjadi kerugian ekonomi bagi masyarakat perkaretan. Penerapan kebijakan bea keluar karet sebaiknya dilakukan bersama-sama dengan kebijakan lain (mixed policy) seperti: a) kebijakan perlindungan terhadap kesejahteraan produsen, b) kebijakan keamanan terhadap perdagangan ilegal bokar, c) kebijakan penyediaan bahan pendukung bagi industri barang jadi karet dan pengurangan/penghapusan PPN bagi produk primer, dan d) kebijakan stabilisasi nilai tukar mata uang (managed floating exchange rate).

Kata kunci: bea keluar, industri barang jadi karet, kesejahteraan, karet alam

\section{PENDAHULUAN}

Karet alam merupakan salah satu komoditas andalan perkebunan sekaligus menjadi komoditas mata-dagangan ekspor. Komoditas karet berperan penting sebagai penghasil devisa negara dan menjadi tumpuan sumber matapencaharian bagi jutaan keluarga petani di pedesaan. Pada tahun 2011, nilai ekspor karet alam Indonesia telah mencapai US\$ 11,8 milyar (LMC International, 2012). 
Karet alam di Indonesia diusahakan oleh Perkebunan Rakyat, Perkebunan Besar Negara, dan Perkebunan Swasta, dimana pada tahun 2011 diperkirakan telah mencapai luasan 3,46 juta hektar dengan produksi 3,14 juta ton (Sekretariat Direktorat Jenderal Perkebunan, 2012). Dari total produksi karet nasional tersebut, sebanyak 2,56 juta ton atau sekitar $83 \%$ diekspor dan kurang lebih 17\% lainnya dikonsumsi oleh industri barang jadi karet di pasar domestik (Badan Pusat Statistik, 2012 dan Departemen Perindustrian, 2012). Ekspor karet alam Indonesia utamanya (96\%) dalam bentuk karet remah Standard Indonesian Rubber (SIR) (LMC International, 2012).

Seperti telah disebutkan di atas bahwa pangsa pasar konsumsi domestik karet alam sebagai bahan baku industri di Indonesia dinilai masih kecil sehingga dalam rangka meningkatkan nilai tambah dan pengembangan industri barang jadi karet di dalam negeri, Pemerintah cq Departemen Perindustrian mewacanakan akan memberlakukan bea keluar bagi karet alam. Rencana pemberlakuan bea keluar sebagai salah satu bentuk dari penerapan kebijakan fiskal dan pengembangan industri barang jadi karet tersebut diharapkan juga akan menghasilkan dan meningkatkan penerimaan pemerintah. Pertanyaannya adalah apakah benar bahwa pemberlakuan bea keluar tersebut sesuai dengan tujuannya yaitu industri hilir karet Indonesia akan berkembang dan menghasilkan tambahan penerimaan bagi pemerintah?. Artikel ini menganalisis dampak dari penerapan bea keluar karet alam terhadap kesejah-teraan dari para pemangku kepentingan industri karet alam Indonesia dengan teknik simulasi.

\section{BAHAN DAN METODE}

\section{Kerangka Pemikiran Teoritik}

Pemerintah yang akan menerapkan kebijakan bea keluar bagi komoditas ekspor bahan baku industri umumnya bertujuan untuk meningkatkan dan melindungi pembeli/pengguna input/konsumen industri berang jadi di dalam negeri, dan menciptakan/meningkatkan penerimaan pemerintah. Bea keluar adalah suatu levies (pungutan) yang diterapkan untuk produk ekspor. Bea keluar dapat berupa: a) nilai tetap per unit levies, b) ad-valorem duties, atau c) gabungan dari nilai tetap per unit levies dan advalorem duties.

Secara teoritik pengaruh penerapan bea keluar terhadap perekonomian suatu komoditas disajikan pada Gambar 1 (Houck, 1986; Sadoulet dab de Janvry, 1995; Tsakok, 1990). Kurva D dan S masing-masing adalah kurva permintaan dan penawaran karet alam Indonesia. Diasumsikan bahwa Indonesia merupakan negara produsen dan pengekspor komoditas karet yang menghadapi harga karet dunia yang ditentukan oleh pasar sehingga kurva ekses permintaan (ED) horisontal. Pada sisi ekspor, kurva ekses penawaran (ES) dari Indonesia dipetakan di sebelah kanan pada Gambar 1b. Tanpa adanya intervensi kebijakan perdagangan pemerintah, kurva ekses permintaan menentukan harga domestik karet sebesar $\mathrm{Op}_{1}$. Pada harga $\mathrm{Op}_{1}$, konsumsi domestik adalah ab, produksi domestik adalah ac dan ekspor adalah bc. Volume ekspor yang sama diindikasikan sebagi df pada Gambar $1 b$.

Jika pemerintah menetapkan bea keluar sebesar Tx, maka kurva ekses penawaran bergeser ke kiri menjadi ES* seperti diperlihatkan pada Gambar $1 \mathrm{~b}$. Penetapan bea keluar ini akan menekan harga domestik karet ke bawah menjadi $\mathrm{Op}_{2}$. Hal ini terjadi karena para pengekspor karet, yang harus membayar bea keluar, dalam kondisi normal akan mengurangi komitmen mereka terhadap ekspor dan tambahan penawarannya akan dipasarkan ke pasar domestik, dalam kondisi normal akan mengurangi komitmen mereka terhadap ekspor dan tambahan penawarannya akan dipasarkan ke pasar domestik. Perbedaan antara $\mathrm{Op}_{1}$ dan $\mathrm{Op}_{2}$ adalah keseimbangan per satuan dari bea keluar. Dengan turunnya harga karet domestik maka pembeli (industri barang jadi karet ban dan non-ban) domestik mendapatkan keuntungan/benefit. Mereka memperoleh karet mentah (karet remah/SIR, Ribbed Smoked Sheet/RSS, dan lateks pekat) yang lebih banyak pada harga yang lebih rendah di sepanjang kurva permintaan D. Jumlah konsumsi karet domestik meningkatkan dari ab ke gh. 


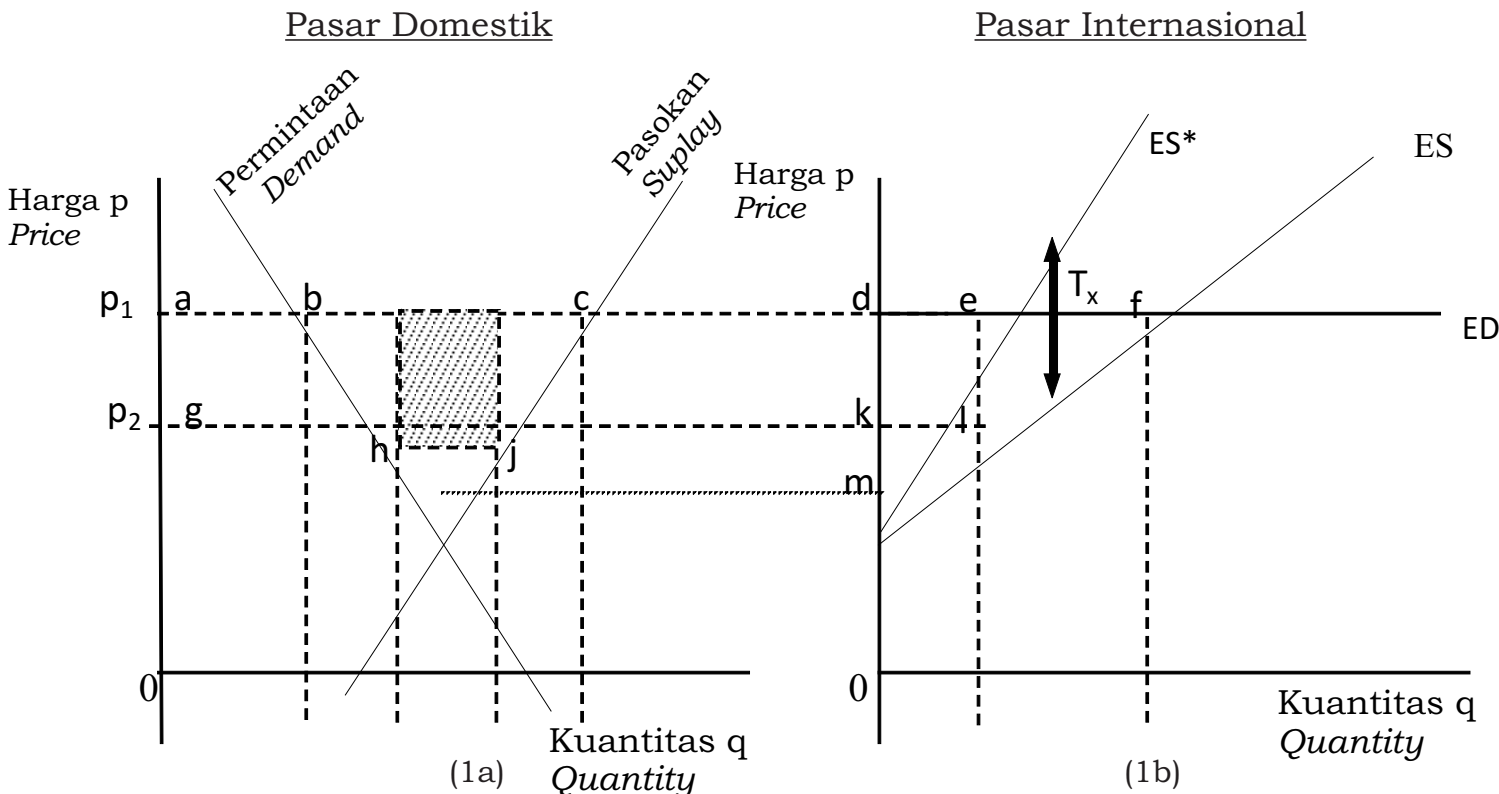

Gambar 1. Penerapan bea keluar karet alam Figure 1. Application of rubber export tax policy

Sebaliknya harga yang rendah merugikan produsen (petani dan pengusaha) karet. Mereka akan memperoleh harga yang lebih rendah dan pada kondisi normal akan mengurangi produksi ke gj, sepanjang kurva penawaran S, dan mengurangi jumlah ekspor menjadi sebesar hj. Pada Gambar 1b, volume ekspor yang lebih kecil ini diindikasikan sebagai kl.

Walaupun menurunkan produksi domestik dan volume ekspor, pengenaan bea keluar akan menghasilkan penerimaan bagi pemerintah. Penerimaan tersebut diindikasikan dengan areal berarsir pada Gambar 1a atau sebesar bidang delk pada Gambar 1b. Area ini adalah nilai bea keluar per unit dikalikan dengan volume yang terkena bea keluar.

Penerapan kebijakan karet akan berdampak terhadap efisiensi dan kesejahteraan masyarakat. Dampak terhadap kesejahteraan tersebut dapat dianalisis dari sisi produsen (producer surplus), konsumen (consumer surplus), penerimaan pemerintah (goverment revenue), dan kerugian sosial (deadweight loss).

\section{Metode Analisis dan Data}

Analisis dampak dari adanya penerapan kebijakan bea keluar karet alam Indonesia terhadap kesejahteraan masyarakat menggunakan pendekatan komparatif statik. Secara rinci dampak penerapan kebijakan bea keluar disajikan pada Gambar 2 (Houck, 1986; Sadoulet dan de Janvry, 1995; Tsakok, 1990). Secara teoritik, penerapan bea keluar dapat mengakibatkan perubahan-perubahan berupa:

a) Penambahan surplus konsumen sebesar $(\mathrm{A}+\mathrm{B})$

b) Pengurangan surplus produsen sebesar $(A+B+C+E+F)$

c) Penambahan penerimaan pemerintah berupa pemasukan dari bea keluar sebesar E

d) Dampak sosial (deadweight loss) berupa kerugian yang harus ditanggung oleh perekonomian akibat pengalihan sumberdaya sebesar $(\mathrm{C}+\mathrm{F})$. C adalah net social loss in consumption (NSLC) dan F adalah net social loss in production (NSLP).

Secara grafis dan kuantitatif, dampak pengenaan bea keluar karet alam seperti disajikan pada Gambar 2 dapat dianalisis sebagai berikut: 


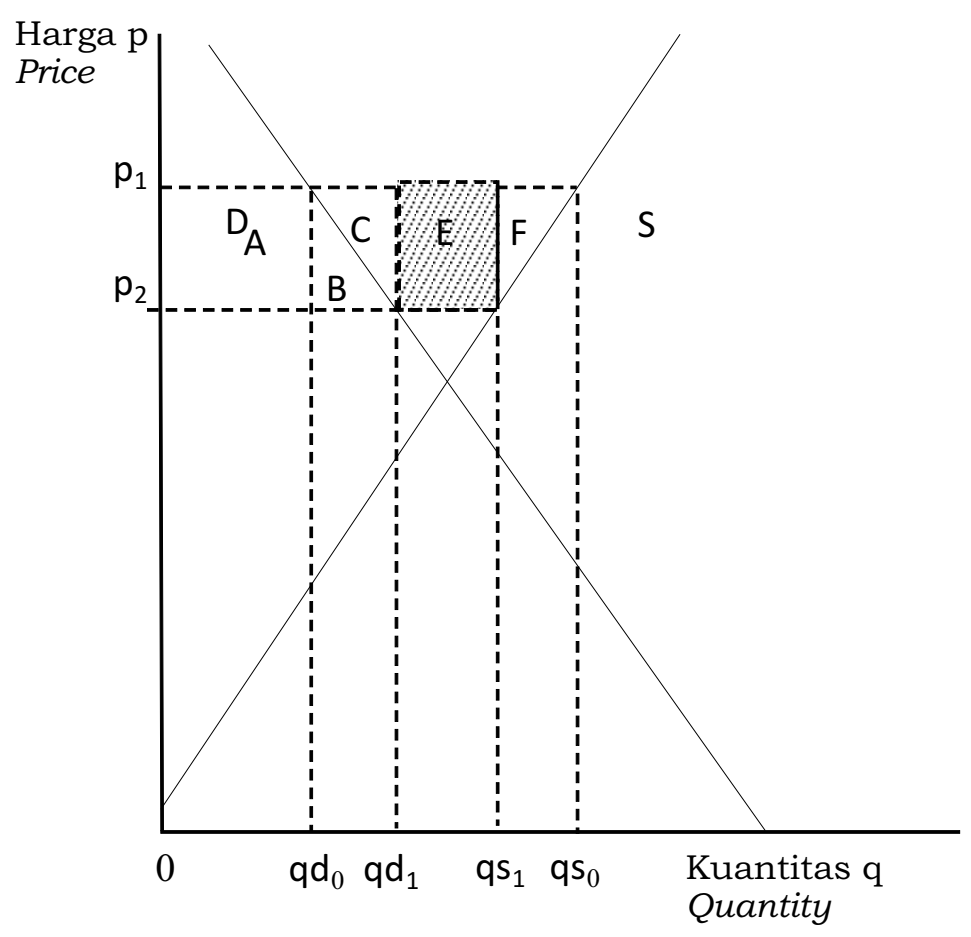

Gambar 2. Perubahan kesejahteraan akibat penerapan bea keluar

Figure 2. Change of welfare due to the imposition of rubber export tax policy

a) Tambahan surplus konsumen industri barang jadi karet adalah sebesar $(A+B)$, secara matematis dapat dihitung dengan formula:

$$
\left.\left(O \mathrm{p}_{1}-O \mathrm{p}_{2}\right) * O \mathrm{Oqd}_{0}\right\}+\left\{\left(O \mathrm{p}_{1}-\mathrm{O} \mathrm{p}_{2}\right) *\left(O \mathrm{qd}_{1}-O \mathrm{Oqd}_{0}\right) / 2\right.
$$

dimana:

$$
\begin{aligned}
& \left(\mathrm{Oqd}_{1}-\mathrm{Oqd}_{0}\right)=\mathrm{Ed} * \mathrm{Tx} * \mathrm{Oqd}_{1} / \mathrm{Op}_{1}, \\
& \left(\mathrm{Op}_{1}-\mathrm{Op}_{2}\right)=\mathrm{Tx} * \mathrm{Op}_{1},
\end{aligned}
$$

Ed adalah elastititas permintaan karet alam Indonesia.

b) Pengurangan surplus produsen (petani, perkebunan besar, dan produsen eksportir SIR, RSS, lateks pekat, dan karet mentah lainnya) adalah sebesar (A $+\mathrm{B}+\mathrm{C}+\mathrm{E}+\mathrm{F}$ ) yang dapat dihitung dengan formula:

$\left[\left\{\left(\mathrm{Op}_{1}-\mathrm{Op}_{2}\right) * \mathrm{Oqs}_{1}\right\}+\left\{\left(\mathrm{Op}_{1}-\mathrm{Op}_{2}\right) *\left(\mathrm{Oqs}_{0}-\mathrm{Oqs}_{1}\right) / 2\right\}\right] . .(2)$

\section{dimana:}

$\left(\mathrm{Oqs}_{0}-\mathrm{Oqs}_{1}\right)=\mathrm{Es} * \mathrm{Tx} * \mathrm{Oqs}_{0} / \mathrm{Op}_{1}$

Es adalah elastisitas penawaran karet alam Indonesia

c) Tambahan penerimaan pemerintah (government revenue) adalah sebesar $\mathrm{E}$, yang dapat dihitung dengan formula:

$\left(\mathrm{Op}_{1}-\mathrm{Op}_{2}\right) *\left(\mathrm{Oqs}_{1}-\mathrm{Oqd}_{1}\right\}$ d) Net social loss in consumption sebesar (C) yang dapat dihitung dengan formula:

$\left(\mathrm{Op}_{1}-\mathrm{Op}_{2}\right) *\left(\mathrm{Oqd}_{1}-\mathrm{Oqd}_{0}\right) / 2$

e) Net social loss in production adalah sebesar $(\mathrm{F})$ yang dapat dihitung dengan formula:

$\left(\mathrm{Op}_{1}-\mathrm{Op}_{2}\right) *\left(\mathrm{Oqs}_{0}-\mathrm{Oqs}_{1}\right) / 2$

Simulasi dampak dari pengenaan bea keluar dilakukan dengan berbagai skenario. Skenario tersebut merupakan kombinasi pengenaan berbagai tingkat bea keluar pada berbagai tingkat nilai tukar sebagai berikut:

a) Skenario tingkat bea keluar sebesar: 6\%, $8 \%$, dan $10 \%$

b) Skenario nilai tukar: Rp 8.000,-/US\$, Rp 8.570,-/US\$, dan Rp 9.500,-/US \$

Skenario di atas akan dianalisis dengan data dasar dan asumsi-asumsi sebagai berikut:

a) Elastisitas permintaan karet alam Indonesia adalah sebesar -0,24 dan elastisitas penawarannya sebesar 0,12 (Hendratno, 2009). 
b) Elastisitas transmisi harga karet alam dunia setelah pengenaan bea keluar ke harga perdagangan besar dan dari harga perdagangan besar ke harga produsen secara berturut-turut masing-masing diasumsikan sebesar 0,96 dan 0,99 (Hendratno, 2009).

c) Jumlah produksi karet alam Indonesia sebesar 3,46 juta ton (Sekretariat Direktorat Jenderal Perkebunan, 2012) dan jumlah ekspornya sebesar 2,57 juta ton (Badan Pusat Statistik, 2012).

d) Rata-rata pangsa produksi karet alam yang berasal dari perkebunan rakyat sebesar 75\% (Sekretariat Direktorat Jenderal Perkebunan, 2012).

e) Konsumsi karet alam domestik dari industri barang jadi karet di Indonesia sebesar 17\% dari produksi (Departemen Perindustrian, 2012 dan Sekretariat Direktorat Jenderal Perkebunan, 2012).

f) Harga karet alam dunia TSR 20 fob Singapura pada tahun 2011 rata-rata sebesar US \$ 4,42 per kg (Singapore Exchange Ltd, 2012).

g) Nilai tukar/kurs beli Bank Indonesia Rp 8.570,-/US\$ (Bank Indonesia, 2012).

h) Harga karet di tingkat perdagangan besar sebesar Rp 37.620,- per kg dan di tingkat petani sebesar Rp 31.970 per kg karet kering $(85 \%$ harga fob SIR 20 Palembang). Harga karet di tingkat perdagangan besar diasumsikan sebagai harga bagi konsumen industri barang jadi karet domestik.

\section{HASIL DAN PEMBAHASAN}

\section{Hasil Analisis Simulasi}

Dampak pengenaan bea keluar karet alam Indonesia akan ditentukan oleh banyak faktor. Identifikasi terhadap berbagai faktor-faktor fundamental yang berpengaruh terhadap pengenaan bea keluar yang paling penting adalah besaran dari bea keluar itu sendiri. Sementara itu faktor-faktor fundamental yang lainnya adalah: a) elastisitas permintaan, b) elastisitas penawaran, c) elastisitas transmisi harga dari pasar dunia ke pasar perdagangan besar, d) elastisitas transmisi harga dari pasar perdagangan besar ke produsen (petani dan perusahaan), e) harga karet alam di pasar dunia, perdagangan besar, dan produsen, f) jumlah produksi, g) jumlah ekspor, h) jumlah konsumsi domestik, i) jumlah impor, dan j) nilai tukar rupiah.

Hasil analisis simulasi dari beberapa skenario pengenaan bea keluar karet dikombinasikan dengan nilai tukar rupiah terhadap US\$ disajikan pada Tabel 1 dan 2 .

Tabel 1 dan 2 menunjukkan bahwa pengenaan bea keluar karet akan menurunkan harga-harga di tingkat perdagangan besar dan produsen. Pengenaan bea keluar sebesar $10 \%$ pada nilai kurs saat ini (Rp 8.570,-/US\$) misalnya, akan menurunkan harga di tingkat perdagangan besar dan produsen masing-masing sebesar Rp 3.456,dan Rp 2.894 per kg karet kering. Pada kondisi tersebut jumlah konsumsi industri barang jadi karet domestik akan meningkat sebesar 12.578 ton dan jumlah produksi karet Indonesia akan menurun sebesar 35.790 ton. Berdasarkan simulasi kombinasi pengenaan bea keluar karet dengan nilai tukar rupiah disimpulkan bahwa peningkatan besaran bea keluar akan menambah penurunan harga di tingkat perdagangan besar dan produsen.

Selanjutnya Tabel 3 menunjukkan bahwa pada kondisi pengenaan bea keluar karet sebesar 10\% misalnya, secara teoritik akan menghasilkan perubahan-perubahan berupa:

a) Surplus konsumen industri barang jadi karet meningkat sebesar Rp 11.077 milyar.

b) Surplus produsen karet menurun sebesar Rp 11.938 milyar.

c) Penerimaan pemerintah sebesar Rp 204 milyar.

d) Efek bersih berupa kerugian perekonomian yang harus ditanggung masyarakat sebesar Rp 657 milyar

Secara umum dapat dikatakan bahwa semakin tinggi pengenaan bea keluar karet yang dikombinasikan dengan semakin melemahnya nilai tukar mata uang maka akan berdampak pada: a) surplus konsumen industri barang jadi karet akan meningkat, b) surplus produsen karet akan menurun, dan c) penerimaan pemerintah akan meningkat. 
Tabel 1. Dampak penerapan bea keluar terhadap perubahan harga-harga

Table 1. Impact of the imposition of rubber export taxe policy on price changes at the wholesale and producers

\begin{tabular}{|c|c|c|}
\hline \multirow[b]{2}{*}{$\begin{array}{l}\text { Skenario } \\
\text { Scenario }\end{array}$} & \multicolumn{2}{|c|}{$\begin{array}{l}\text { Tambahan nilai } \\
\text { Value added }\end{array}$} \\
\hline & $\begin{array}{l}\text { Harga di tingkat } \\
\text { perdagangan besar } \\
\text { Wholesale price } \\
\text { (Rp/kg SIR 20) }\end{array}$ & $\begin{array}{c}\text { Harga di tingkat } \\
\text { produsen } \\
\text { (Rp/kg karet kering) } \\
\text { Producer price } \\
\text { (Rp/kg dry rubber) }\end{array}$ \\
\hline \multicolumn{3}{|c|}{ Bea keluar karet $10 \%$} \\
\hline 1. Kurs Rp $9.500 / U S \$$ & -3.931 & -3.208 \\
\hline 2. Kurs Rp $8.570 / U S \$$ & -3.546 & -2.894 \\
\hline 3. Kurs Rp $8.000 /$ US $\$$ & -3.310 & -2.701 \\
\hline \multicolumn{3}{|c|}{ Bea keluar karet $8 \%$} \\
\hline 1. Kurs Rp $9.500 /$ US $\$$ & -3.145 & -2.566 \\
\hline 2. Kurs Rp $8.570 / U S \$$ & -2.837 & -2.315 \\
\hline 3. Kurs Rp $8.000 / U S \$$ & -2.648 & -2.161 \\
\hline \multicolumn{3}{|c|}{ Bea keluar karet 6\% } \\
\hline 1. Kurs $\operatorname{Rp} 9.500 / \mathrm{US} \$$ & -2.358 & -1.925 \\
\hline 2. Kurs Rp $8.570 / U S \$$ & -2.127 & -1.736 \\
\hline 3. Kurs Rp $8.000 / U S \$$ & -1.986 & -1.621 \\
\hline
\end{tabular}

\section{Analisis Empiris dan Implikasi}

Analisis empiris memperkirakan bahwa penerapan bea keluar karet memang akan meningkatkan penerimaan pemerintah, tetapi di sisi lainnya juga akan dapat menurunkan harga bokar petani sehingga kesejahteraan petani karet akan menurun. Dampak lainnya juga memungkinkan terjadinya kerugian yang harus ditanggung oleh perekonomian nasional akibat perubahan alokasi sumberdaya oleh produsen karet dan konsumen industri barang jadi karet, sementara itu pengembangan industri barang jadi karet ban dan non-ban di tingkat domestik/nasional sebenarnya masih diragukan.

Dampak penerapan bea keluar yang menurunkan harga bokar selanjutnya akan berlanjut pada penurunan tingkat pendapatan dan kesejahteraan petani yang mengelola sekitar 85\% dari luas areal karet

Tabel2. Dampak penerapan bea keluar terhadap perubahan konsumsi domestik dan produksi karet

Table 2. Impact of the imposition of rubber export taxe policy on changes in domestic consumption and production of rubber

\begin{tabular}{|c|c|c|}
\hline \multirow{2}{*}{$\begin{array}{l}\text { Skenario } \\
\text { Scenario }\end{array}$} & \multicolumn{2}{|c|}{$\begin{array}{c}\text { Tambahan kuantitas } \\
\text { Quantity added }\end{array}$} \\
\hline & $\begin{array}{l}\text { Jumlah konsumsi domestik karet (ton) } \\
\text { Domestic rubber consumption (tonnes) }\end{array}$ & $\begin{array}{l}\text { Jumlah produksi karet (ton) } \\
\text { Rubber production (tonnes) }\end{array}$ \\
\hline Bea keluar karet $10 \%$ & 12578 & -35790 \\
\hline Bea keluar karet 8\% & 10062 & -28631 \\
\hline Bea keluar karet 6\% & 7547 & -21473 \\
\hline
\end{tabular}


Tabel 3. Dampak penerapan bea keluar karet dan nilai tukar terhadap kesejahteraan Table 3. Impact of the imposition of rubber export taxe policy and exchange rates on welfare condition

\begin{tabular}{|c|c|c|c|c|}
\hline \multirow[b]{2}{*}{$\begin{array}{l}\text { Skenario } \\
\text { Scenario }\end{array}$} & \multicolumn{4}{|c|}{$\begin{array}{c}\text { Perubahan kesejahteraan } \\
\text { Welfare changes }\end{array}$} \\
\hline & $\begin{array}{l}\text { Surplus konsumen } \\
\text { industri barang jadi karet } \\
\text { Rubber goods industry } \\
\text { consumer surplus } \\
\text { (Rp milyar) }\end{array}$ & $\begin{array}{c}\text { Surplus produsen } \\
\text { karet } \\
\text { Rubber producer } \\
\text { surplus } \\
\text { (Rp milyar) }\end{array}$ & $\begin{array}{l}\text { Penerimaan } \\
\text { pemerintah } \\
\text { Goverment } \\
\text { revenue } \\
\text { (Rp milyar) }\end{array}$ & $\begin{array}{r}\text { Efek bersih } \\
\text { Clean effect } \\
\text { (Rp milyar) }\end{array}$ \\
\hline \multicolumn{5}{|c|}{ Bea keluar karet $10 \%$} \\
\hline Kurs Rp 9.500/US\$ & 12248 & 13.125 & 226 & -620 \\
\hline Kurs Rp 8.570/US\$ & 11077 & -11.938 & 204 & -657 \\
\hline Kurs Rp 8.000/US\$ & 10399 & -11.211 & 190 & -680 \\
\hline \multicolumn{5}{|c|}{ Bea keluar karet 8\% } \\
\hline Kurs Rp 9.500/US\$ & 9799 & 10.534 & 112 & -621 \\
\hline Kurs Rp 8.570/US\$ & 8840 & -9.581 & 101 & -639 \\
\hline Kurs Rp 8.000/US\$ & 8252 & -8.997 & 94 & -649 \\
\hline \multicolumn{5}{|c|}{ Bea keluar karet 6\% } \\
\hline Kurs Rp 9.500/US\$ & 7332 & -7.926 & 33 & -560 \\
\hline Kurs Rp 8.570/US\$ & 6614 & -7.208 & 29 & -564 \\
\hline Kurs Rp 8.000/US\$ & 6174 & -6.769 & 27 & -566 \\
\hline
\end{tabular}

di Indonesia. Kekhawatiran mengenai efek lanjutannya adalah bahwa bagi petani yang telah mengembangkan kebun dengan klonklon karet unggul (diperkirakan sebesar $\pm 50-60 \%$ dari perkebunan karet rakyat), mereka akan berusaha untuk mengurangi biaya pemeliharaan kebunnya akibat kekurangan modal, sehingga produksi karet juga akan dapat menurun. Efek domino yang lebih rawan dari penurunan/ rendahnya harga bokar khususnya yang terjadi di wilayah dekat dengan perbatasan misalnya, adalah dapat meningkatkan terjadinya penjualan illegal bokar ke negara tetangga akibat harga bokar di negara tetangga yang relatif akan lebih tinggi.

Sementara itu keraguan mengenai dampak pengenaan bea keluar terhadap perkembangan industri barang jadi karet domestik seperti a) industri ban (ban sepeda motor, sepeda, kendaraan penumpang, truk, bus, pesawat terbang, kendaraan berat, dll) dan produk terkait (ban dalam, pentil, dll), b) industri barang teknik dan otomotif (conveyor belt, komponen otomotif, komponen elektronik, rol karet, bearing, d1l), c) industri barang jadi lateks (sarung tangan, kondom, benang karet, balon, spignomanometer, kateter, busa, dll), dan d) industri barang jadi karet untuk keperluan umum (karpet, alas kaki, barang olah raga, alat rumah tangga, dil) adalah karena struktur dan sistem pengembangan industri barang jadi karet sangat kompleks, sedangkan rata-rata pemakaian karet alam dalam industri barang jadi karet untuk ban misalnya, dinilai kecil yaitu hanya sebesar $\pm 40 \%$ saja. Pengembangan industri barang jadi karet domestik memerlukan dukungan dari industri lainnya untuk pengadaan bahan baku, bahan kimia, permesinan, dan sarana utilitasnya (Gambar 3). Sementara itu status pengadaan bahan-bahan pendukung untuk industri barang jadi karet masih banyak yang harus diimpor (Tabel 4).

Penerapan bea keluar karet di satu sisi diperkirakan akan dapat menimbulkan dampak positif (berupa peningkatan penerimaan pemerintah) namun di sisi lainnya juga menimbulkan dampak negatif (berupa penurunan surplus produsen petani dan pengusaha karet, serta kerugian perekonomian nasional akibat perubahan alokasi sumberdaya di tingkat produsen dan konsumen industri barang jadi karet. Sementara itu dampak terhadap penambahan surplus konsumen industri barang jadi karet domestik masih diragukan akan dapat menjadi kenyataan karena pengembangan industri barang jadi karet 


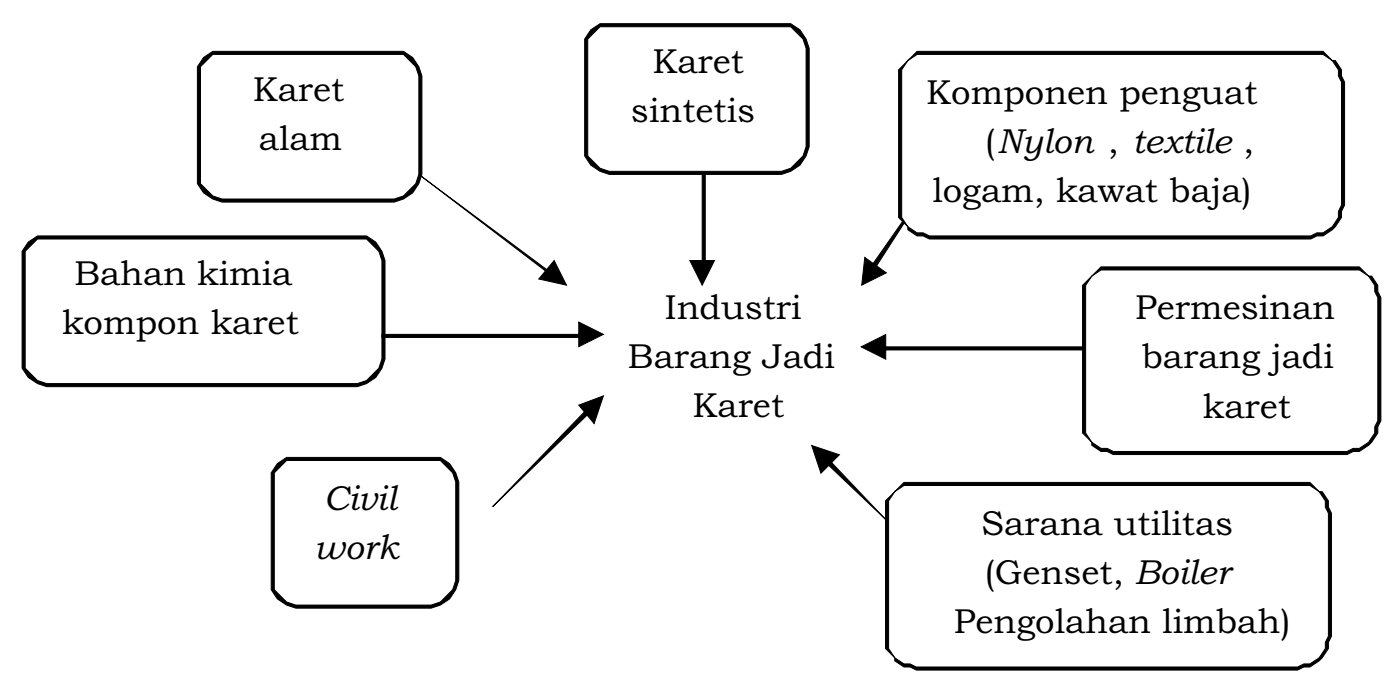

Gambar 3. Pengembangan industri barang jadi karet dan pendukungnya

Figure 3. Development of rubber goods industry and its supporting facilities

domestik membutuhkan sistem dan proses yang komplek yang membutuhkan waktu dan komitmen untuk dapat merealisasikannya.

Penentuan besaran dari kebijakan pengenaan bea keluar karet alam juga harus diperhitungkan dengan matang. Jika kebijakan bea keluar karet (dalam besaran tertentu yang efektif) tetap akan diberlakukan oleh pemerintah maka diperlukan penerapan kebijakan lainnya sebagai kebijakan campuran (mixed policy) dalam upaya mencapai optimalisasi

Tabel 4. Sumber bahan baku dan bahan pendukung industri barang jadi karet Table 4. Sources of raw and supported materials for industrial rubber goods

\begin{tabular}{lcc} 
& \multicolumn{2}{c}{ Sumber pengadaan } \\
Saw baku dan bahan pendukung & \multicolumn{2}{c}{ Source } \\
\cline { 2 - 3 } Raw materials and supporting materials & Lokal & $\begin{array}{c}\text { Impor } \\
\text { Import }\end{array}$ \\
\cline { 2 - 3 } 1. Karet alam & $\mathrm{x}$ & $\mathrm{x}$ \\
2. Karet sintetik & & $\mathrm{x}$ \\
- Karet penggunaan umum (SBR) & $\mathrm{x}$ & $\mathrm{x}$ \\
- Karet tahan panas (CR) & & $\mathrm{x}$ \\
- Karet tahan minyak (NBR) & & $\mathrm{x}$ \\
- Karet tahan degradasi (EPDM) & & $\mathrm{x}$ \\
- Karet khusus (PU, Butil, IIR) & & $\mathrm{x}$ \\
3. Aktivator (ZnO, asam sterat) & $\mathrm{x}$ & $\mathrm{x}$ \\
4. Pemvulkanisasi, sulfur & $\mathrm{x}$ & $\mathrm{x}$ \\
5. Pemvulkanisasi khusus, oksida logam & & $\mathrm{x}$ \\
6. Softener & $\mathrm{x}$ & $\mathrm{x}$ \\
7. Black Filler (carbon black) & $\mathrm{x}$ & $\mathrm{x}$ \\
8. White Filler (kaolin, silika, CaCo3) & $\mathrm{x}$ & $\mathrm{x}$ \\
9. Akselerator & & $\mathrm{x}$ \\
10. Antioksidan & &
\end{tabular}


tujuannya sekaligus mengurangi risiko terjadinya dampak negatif lain yang tidak diharapkan. Kebijakan campuran lain yang dapat dilakukan secara bersama adalah:

1) Kebijakan perlindungan terhadap kesejahteraan produsen (petani dan pengusaha karet) baik ditinjau dari sisi produksi (misalnya: subsidi dan penyediaan input produksi karet, pengembangan infrastruktur, d1l) maupun konsumsi (misalnya: subsidi dan penyediaan bahan kebutuhan pokok di pedesaan), karena petani selain berfungsi sebagai produsen karet juga sebagai konsumen dari barang-barang kebutuhan pokok.

2) Kebijakan pengamanan terhadap penjualan illegal bokar ke negara tetangga khususnya di wilayah perbatasan.

3) Kebijakan khusus pengembangan barang jadi karet domestik dengan memberi fasilitasi, mendorong, dan menyediakan bahan pendukung (misalnya melalui kebijakan investasi, kemudahan impor bahan pendukung, dan mesin produksi). Penghapusan/ pengurangan PPN Produk Primer juga diperlukan.

4) Kebijakan stabilisasi neraca perdagangan melalui pengendalian nilai tukar mata uang rupiah terhadap US\$ (managed floating exchange rate)

\section{KESIMPULAN} kan:

Dari hasil penelitian dapat disimpul-

1) Dampak pengenaan bea keluar karet utamanya dipengaruhi oleh besaran dari bea keluar yang akan diterapkan. Sementara itu faktor-faktor fundamental lain yang mempengaruhinya adalah: a) elastisitas permintaan, b) elastisitas penawaran, c) elastisitas transmisi harga dari pasar dunia ke pasar perdagangan besar, d) elastisitas transmisi harga dari pasar perdagangan besar ke produsen (petani dan perusahaan), e) harga karet alam di pasar dunia, perdagangan besar, dan produsen, f) jumlah produksi, g) jumlah ekspor, h) jumlah konsumsi domestik, i) jumlah impor, dan j) nilai tukar rupiah.
2) Pengenaan bea keluar karet akan menurunkan harga-harga di tingkat perdagangan besar dan produsen. Peningkatan besaran bea keluar akan menambah penurunan harga-harga di tingkat perdagangan besar dan produsen tersebut.

3) Pengenaan bea keluar karet akan: a) meningkatkan surplus konsumen industri barang jadi, b) menurunkan surplus produsen (petani dan perusahaan), c) meningkatkan penerimaan pemerintah, dan d) terdapat kerugian ekonomi yang harus ditanggung oleh masyarakat. Semakin tinggi pengenaan bea keluar karet yang dikombinasikan dengan semakin melemahnya nilai tukar mata uang rupiah akan berdampak pada: a) surplus konsumen industri barang jadi karet meningkat, b) surplus produsen karet menurun, dan c) penerimaan pemerintah meningkat

4) Kebijakan bea keluar karet harus diperhitungkan dengan matang. Jika kebijakan bea keluar karet diberlakukan maka diperlukan penerapan kebijakan lain/campuran (mixed policy) dalam upaya mencapai optimalisasi tujuannya sekaligus mengurangi risiko terjadinya dampak negatif lain yang tidak diharapkan. Kebijakan campuran yang dapat dilakukan secara bersama-sama dengan kebijakan penerapan bea keluar karet yang disarankan adalah:

a) Kebijakan perlindungan terhadap kesejahteraan produsen dari sisi produksi (misalnya: subsidi dan penyediaan input produksi karet, pengembangan infrastruktur, dll) maupun konsumsi (misalnya: subsidi dan penyediaan bahan kebutuhan pokok di pedesaan).

b) Kebijakan pengamanan terhadap penjualan illegal bahan olah karet ke negara tetangga

c) Kebijakan pengembangan bahan pendukung untuk industri barang jadi karet domestik dan penghapusan/pengurangan PPN Produk Primer.

d) Kebijakan stabilisasi neraca perdagangan melalui pengendalian nilai tukar mata uang (managed floating exchange rate) 


\section{DAFTAR PUSTAKA}

Bank Indonesia. 2012. Kurs uang kertas asing mata uang USD: kurs beli pada Januari sd Maret tahun 2011. www.bi.go.id diakses tanggal 30 Maret 2012.

Badan Pusat Statistik. 2012. Data Ekspor Karet. Belum dipublikasi. Badan Pusat Statistik, Jakarta.

Departemen Perindustrian. 2012. Perkembangan produksi dan konsumsi karet alam pada industri barang karet dalam negeri tahun 2001 - 2011. Belum dipublikasi. Departemen Perindustrian, Jakarta.

Hendratno, S. 2009. Pendugaan harga harian pada futures trading dan integrasi pasar karet alam. J. Penel. Karet, 27 (2).

Hendratno, S. 2009. Model pasar karet alam Indonesia. Tidak dipublikasi. Balai Penelitian Sembawa, Pusat Penelitian Karet, Palembang.
Houck, J. P. 1986. Elements of Agricultural Trade Policies. Macmillan Publishing Company, New York.

LMC International. 2012. Rubber Bulletin, March 2012. LMC International Ltd.

Tsakok, I. 1990. Agricultural Price Policy. Cornell University Press, Ithaca and London.

Sadoulet, E. and A. de Janvry. 1995. Quantitative Development Policy Analysis. The John Hopkins University Press, Baltimore and London.

Singapore Exchange Ltd. 2012. SICOM TSR 20 rubber futures: daily price, historical data 2011. www.sgx.com diakses tanggal 27 Maret 2012.

Sekretariat Direktorat Jenderal Perkebunan. 2012. Statistik Perkebunan: Karet. Belum dipublikasi. Sekretariat Direktorat Jenderal Perkebunan, Jakarta. 